\title{
Chimeric Antigen Receptor T Cells: A Race to Revolutionize Cancer Therapy
}

\author{
Marion Subklewe $\mathrm{e}^{\mathrm{a}-\mathrm{d}}$ Michael von Bergwelt-Baildon ${ }^{\mathrm{a}, \mathrm{c}, \mathrm{d}} \quad$ Andreas Humpe $^{\mathrm{e}}$

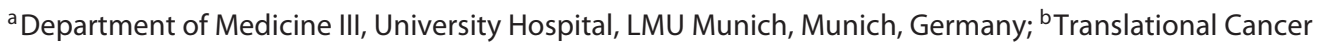 \\ Immunology, Gene Center, LMU Munich, Munich, Germany; 'German Cancer Consortium (DKTK), Heidelberg, \\ Germany; ${ }^{d}$ German Cancer Research Center (DKFZ), Heidelberg, Germany; ${ }^{e}$ Department of Transfusion Medicine, \\ Cellular Therapy and Hemostasiology, University Hospital, LMU Munich, Munich, Germany
}

\section{Keywords}

Chimeric antigen receptor T cells · Cancer immunotherapy · Lymphoma $\cdot$ Toxicities solid tumors. This review covers the development and current status of CAR T-cell therapy in a clinical setting with focus on challenges and future opportunities.

(c) 2019 S. Karger AG, Basel

\section{Introduction: Immunotherapy Coming of Age}

For many decades, oncologists have used the potential and characteristics of the body's immune system within the scope of immuno-oncological therapies. Increased knowledge about the characteristics of leukemic cells has led to the development of allogenic stem cell transplantation (alloSCT) - the mother of immunotherapy. alloSCT has clearly shown the potential of T cells to eliminate leukemia cells. In his 1998 publication, Kolb [1] presented evidence hereof by showing that donor lymphocyte transfusions can induce lasting remission in patients with relapsed chronic myeloid leukemia.

An alternative strategy to direct T cells to leukemia or lymphoma cells is the bispecific T-cell-recruiting antibody construct CD19 $\times$ CD3 [2]. These bispecific T-cell engagers (BiTEs) are composed of two single-chain variable fragments, one targeting a tumor-associated antigen, the other targeting a T-cell-associated antigen.

\section{KARGER}

(C) 2019 S. Karger AG, Basel 
Through binding of CD3 of the T-cell receptor complex, BiTEs recruit $\mathrm{T}$ cells irrespective of their antigen specificity, leading to $\mathrm{T}$-cell activation and tumor cell lysis. Blinatumomab is the first-in-class BiTE antibody construct targeting CD19 in B-cell malignancies $[3,4]$. The European Commission has only very recently, in June 2018, granted blinatumomab full EU approval for the treatment of Philadelphia chromosome-negative relapsed/refractory B-cell precursor acute lymphoblastic leukemia ( $\mathrm{r} / \mathrm{r}$ ALL) after almost 3 years of conditional market authorization [5]. In November 2018 the Committee for Medicinal Products for Human Use recommended to extend the marketing authorization for patients with minimal residual disease.

Although clinical trials have shown that blinatumom$a b$ can be a very effective treatment, more than half of all $\mathrm{r} / \mathrm{r}$ ALL patients were nonresponders [6, 7]. Patients with a bone marrow blast below $50 \%$ had the highest complete remission rate (CR; 73\%), whereas patients with a high tumor burden ( $>50 \%$ bone marrow blast) had a much lower response rate (29\%) [6]. Also, long-term survival has been shown to correlate with a significant T-cell expansion [4]. A study investigating the role of regulatory $\mathrm{T}$ cells in predicting the outcome of blinatumomab treatment found that a high percentage of regulatory $\mathrm{T}$ cells results in a lower patient response rate and that in preclinical models, the depletion of regulatory $\mathrm{T}$ cells in nonresponding ALL patients restored T-cell proliferation [8].

A promising advance to overcome some of these issues is the introduction of chimeric antigen receptor (CAR) $\mathrm{T}$ cells: a patient's own T cells that are reengineered ex vivo to express a CAR. This review covers the development and current status of CAR T cells in a clinical setting with focus on challenges and future opportunities.

\section{The CAR T-Cell Family}

CAR T cells are genetically engineered hybrids of antibodies and $\mathrm{T}$ cells with an antibody-like surface domain, a transmembrane domain and an intracellular signaling domain. The extracellular part consists of heavy and light chains derived of an antibody to form a single-chain variable fragment. It redirects the specificity of the receptor to recognize tumor antigens independently of major histocompatibility complex proteins. The transmembrane domain connecting the extra- and intracellular part is typically constructed from CD8 or IgG4 molecules. T-cell activation is derived by an intracellular signaling domain consisting of a costimulatory domain and the $\mathrm{CD} 3 \zeta$ chain.

CD19 has been chosen as the most frequent target antigen for several reasons: first, its frequent and high-level expression in B-cell leukemias and lymphomas; second, its broader and higher expression relative to other poten- tial targets like CD20 or CD22; and third, its confinement to the $\mathrm{B}$-cell lineage in healthy tissue. Consequently, Bcell aplasia is a common on-target occurrence following CAR T-cell infusion that can be alleviated by monthly replacement therapy with intravenous immunoglobulin.

The design of the receptors has considerably evolved over the years. First-generation CARs were engineered with only the $\mathrm{CD} 3 \zeta$ domain. They were not able to prime resting $\mathrm{T}$ cells and direct lasting $\mathrm{T}$-cell responses or sustained cytokine release, due to their limited signaling capability $[9,10]$. The coupling with additional costimulatory signaling domains (e.g., CD28 or 4-1BB) led to improved activation, enhanced survival and effective expansion of the modified T cells $[11,12]$. These secondgeneration receptors in the form of "living drugs" are the basis of currently approved CAR T-cell therapy. Thirdgeneration CAR $\mathrm{T}$ cells combine the signaling potential of two costimulatory domains (e.g., both CD28 and 4-1BB). The antitumor activity of fourth-generation CARs, also called TRUCKs (T-cells redirected for universal cytokine-mediated killing), is enhanced by further genetic modification. These include, amongst others, additional transgenes for cytokine secretion (e.g., IL-12) or additional costimulatory ligands [13-15] (Fig. 1).

\section{The Mechanics of CAR T Cells}

The manufacturing of CAR T cells is a complex and carefully controlled procedure. It starts with the collection of unstimulated leukocytes via leukapheresis. The separation of T cells can be achieved in various ways: density gradients remove red blood cells and platelet contaminants; other devices divide cells by size and density, eliminate monocytes and isolate lymphocytes. An additional step enables further separation into CD4, CD8, CD25 or CD62L T-cell subsets [16-18]. The process of T-cell enrichment differs between the approved products and clinical indications. Accordingly, the starting material for CAR T production differs between Yescarta and Kymriah albeit the relevance in relation to safety and efficacy is incompletely understood.

The harvested and T-cell-enriched starting populations are genetically modified with viral vectors. Lentiviral vectors provide a safer genomic integration profile than gammaretroviral vectors [19], thus have been commonly used in clinical trials of CAR T-cell therapies [20]. The transposon/transposase system is a newer plasmidbased expression system that implements anti-CD19 CARs into T cells by electroporation [21].

CAR T cells are activated either with the use of antiCD3 antibodies, anti-CD3/anti-CD28 immunomagnetic beads [22], or antigen-presenting cells like dendritic cells or artificial antigen-presenting cells [23]. The latter can 


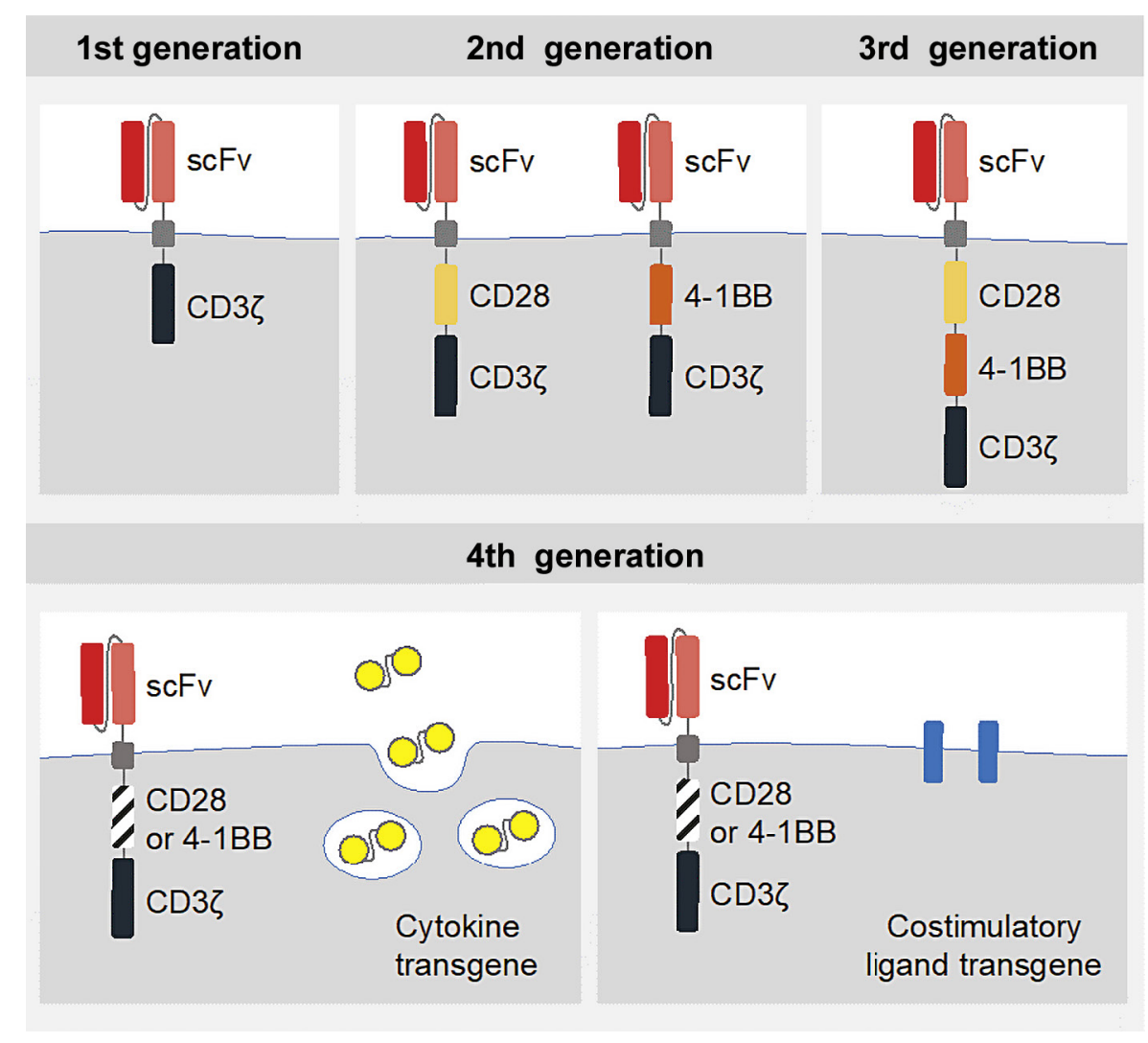

Fig. 1. Evolution of CAR generations. Firstgeneration CARs consist of the $\mathrm{CD} 3 \zeta$ alone, whereas the second generation includes additional costimulatory signaling domains (CD28 or 4-1BB). The third generation combines two costimulatory domains (e.g., CD28 and 4-1BB). Fourth-generation CARs are additionally armored with genes that enable, for example, the expression of cytokines. scFV, single-chain variable fragment; $\mathrm{CD} 3 \zeta$, cluster of differentiation 3 zeta; $\mathrm{CD} 28+4-1 \mathrm{BB}$, costimulatory signaling domains. Adapted from Brentjens and Curran [13].

be equipped with various costimulatory ligands to ensure proliferation. In order to generate therapeutic doses of CAR T cells, several platforms are available that allow for rapid cell expansion and low risk of contamination [16$18]$. Both commercial products are generated by unspecific stimulation utilizing CD3/CD28 beads and defined cytokines; however, details are not completely revealed by the companies due to intellectual property considerations.

After blood collection and manufacturing of the patient-specific CAR T-cell product, the frozen cells are delivered to the treatment center and thawed. The final step is a single infusion of the CAR T cells into the patient, which is preceded by a lymphodepleting chemotherapy to promote expansion (Fig. 2).

\section{CARs Crossing the Finish Line}

CAR T-cell therapy has developed rapidly over the last few years. The astounding successes seen with this "adoptive cell immunotherapy" in cancer treatment have led to the first two CAR T-cell medicines being granted marketing authorization for hematological cancer indications in the USA last year. In August 2018, the European Commission followed suit by approving tisagenlecleucel $\left(\right.$ Kymriah $^{\circledR}$, Novartis) and axicabtagene ciloleucel (Yes-

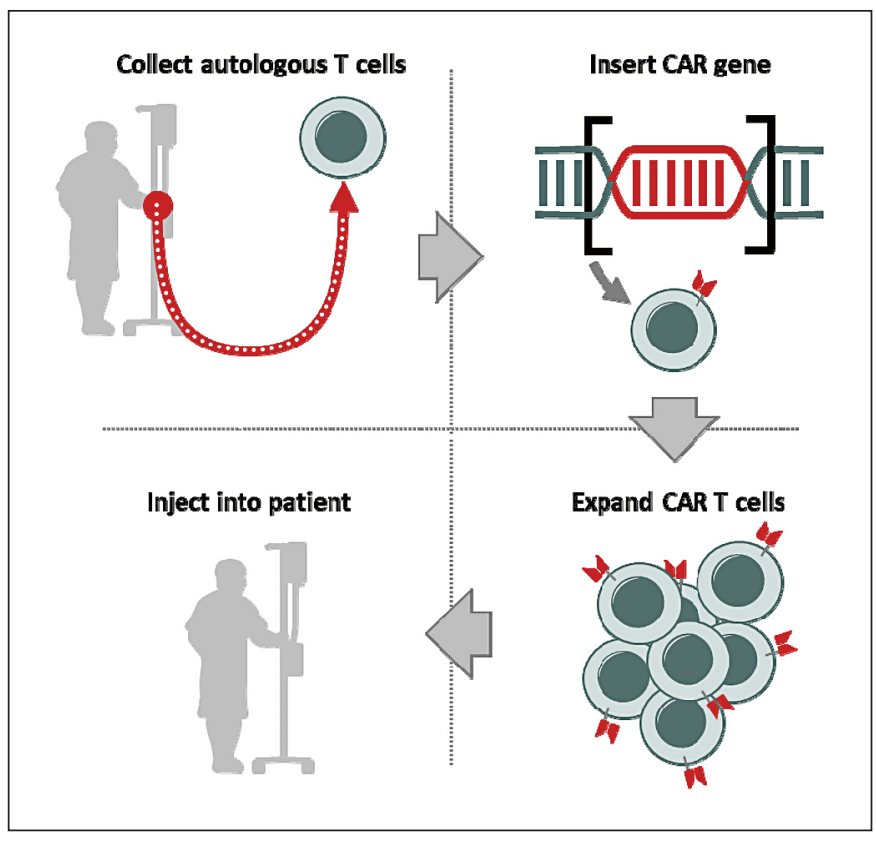

Fig. 2. CAR T-cell therapy. T cells are collected from the patient and genetically modified to include antigen receptors that combine the single-chain variable fragment of an antibody with intracellular signaling domains. Thus, they can recognize tumor cells expressing a tumor-associated antigen using lentiviral-vector technology. Engineered CAR T cells are expanded in the laboratory and transfused back into the patient. 
carta $^{\circledR}$, Gilead) for the treatment of childhood/young adult $\mathrm{r} / \mathrm{r}$ B-cell precursor ALL and aggressive non-Hodgkin lymphoma (NHL: diffuse large B-cell lymphoma, DLBCL; primary mediastinal large B-cell lymphoma).

\section{Childhood/Young Adult B-Cell Precursor ALL}

The pivotal global ELIANA trial (NCT02435849) investigated the therapeutic use of tisagenlecleucel, a CD19directed genetically modified autologous $\mathrm{T}$-cell product, in pediatric and young adult patients with $\mathrm{r} / \mathrm{r}$ B-cell ALL. In this phase II trial, tisagenlecleucel was given as a single infusion to a total of 75 patients. Analysis of the latest long-term results from the ELIANA study were published earlier this year. At enrolment, patients had a median of 3 prior therapies, with $61 \%$ of patients having received prior alloSCT. The overall remission rate (CR/CRi) was $81 \%$ with median follow-up of more than a year. Eventfree survival and overall survival at 6 months were 73 and $90 \%$, respectively, with median duration of remission not reached. Tisagenlecleucel was detected in patients for as long as 20 months, demonstrating long-term persistence [24]. The 4-1BB domain contained in tisagenlecleucel has been suggested to ameliorate $\mathrm{T}$-cell exhaustion and thereby improve the persistence of CAR T cells [25]. It is currently unclear whether prolonged persistence of the 19$41 \mathrm{BB}$ CAR T cells is important and would lead to better long-term survival [26].

Kymriah ${ }^{\circledR}$ became the first CAR T-cell therapy to gain market access by the US Food and Drug Administration (FDA) in August 2017 for refractory CD19-positive Bcell ALL [27]. On August 27, 2018, the European Commission has approved Kymriah ${ }^{\circledR}$ for the treatment of pediatric and young adult patients up to 25 years of age with B-cell ALL that is refractory, in relapse aftertransplantation or in second or later relapse. Tisagenlecleucel is currently the only CAR T-cell therapy to receive FDA and European Commission approval for $\mathrm{r} / \mathrm{r}$ childhood ALL.

\section{Non-Hodgkin Lymphoma: DLBCL, Primary \\ Mediastinal B-Cell Lymphoma}

CAR T-cell therapies with tisagenlecleucel and axicabtagene ciloleucel have further been successfully studied in two large B-cell lymphoma subtypes (see also Table 1).

"JULIET" (NCT02445248), led by researchers at the University of Pennsylvania, was the pivotal global registration study for tisagenlecleucel in adult patients with $\mathrm{r} / \mathrm{r}$ large B-cell lymphoma after two or more lines of systemic therapy, including DLBCL not otherwise specified, high-grade B-cell lymphoma, and DLBCL arising from follicular lymphoma. In a population of 68 patients with relapsed or refractory disease, the objective response rate was $50 \%$ with a CR rate of $32 \%$, and for responders, the median duration of response was not reached after a me- dian follow-up of 9.4 months. This response rate exceeded those previously reported for standard chemotherapy.

In June 2018, Novartis announced 14-month results from the JULIET trial. Tisagenlecleucel showed ongoing durable responses in adult patients with $\mathrm{r} / \mathrm{r}$ DLBCL. The overall response rate was $52 \%$ among 93 patients. Median duration of response was not reached at a median followup of 14 months. A CR was achieved in $40 \%$ of patients, and $12 \%$ achieved a partial response. Patients had a $65 \%$ chance of being relapse-free 1 year after onset of response. With 8 months of additional follow-up, response rates remained consistent with previous reports, and the safety profile was maintained with no emergence of new safety signals [20].

In May 2018, the FDA approved Kymriah ${ }^{\circledR}$ for the treatment of adult patients with $\mathrm{r} / \mathrm{r}$ large B-cell lymphoma after two or more lines of systemic therapy including DLBCL, high-grade B-cell lymphoma and DLBCL arising from follicular lymphoma based on data from the JULIET study. On August 27, 2018, the approval for Kymriah ${ }^{\circledR}$ in $r / r$ DLBCL after two or more lines of systemic therapy was granted in the EU.

Axicabtagene ciloleucel (Yescarta ${ }^{\circledR}$ ), like tisagenlecleucel, is a CD19-directed, genetically modified, autologous T-cell immunotherapy designed to kill CD19-positive B cells including tumor cells. However, the two products differ in several respects, the main being that Yescarta ${ }^{\circledR}$ uses a retroviral vector to transduce $\mathrm{T}$ cells and the intracellular domain of CD28 to costimulate T cells, while Kymriah $^{\circledR}$ uses a lentiviral vector and the intracellular domain from 4-1BB for the same purposes. The pivotal phase I-II ZUMA-1 trial (NCT02348216) investigated axicabtagene ciloleucel in adult patients with refractory aggressive NHL. In the single-arm trial, $72 \%$ of patients $(n=73 / 101)$ who received a single infusion of axicabtagene ciloleucel responded to therapy, with $51 \%(n=52 / 101)$ achieving a $\mathrm{CR}$ (as assessed by an independent review committee, median follow-up of 15.1 months). At 1 year following infusion, $60 \%$ of patients were alive and the median overall survival had not been reached $[28,29]$.

Yescarta ${ }^{\circledR}$ was approved by the FDA in October 2017 for treatment of adult patients with relapsed or refractory large B-cell lymphoma after two or more lines of systemic therapy including DLBCL not otherwise specified, primary mediastinal large B-cell lymphoma, high-grade Bcell lymphoma, and DLBCL arising from follicular lymphoma [30]. Almost 1 year later, on August 27, 2018 - the same day that marketing authorization was granted for Kymriah $^{\circledR}$ - the European Commission also approved authorization for Yescarta ${ }^{\circledR}$ in the EU.

Axicabtagene ciloleucel represents a significantly improved treatment option for patients with refractory, aggressive NHL compared with previously available therapies [31]. This was demonstrated in a comparative analy- 
Table 1. Summary of the clinical trials for treatment of $\mathrm{r} / \mathrm{r}$ DLBCL/PMBCL

\begin{tabular}{|c|c|c|c|}
\hline & JULIET (tisagenlecleucel) & ZUMA-1 (axicabtagene ciloleucel) & $\begin{array}{l}\text { TRANSCEND NHL } 001 \\
\text { (lisocabtagene maraleucel) }\end{array}$ \\
\hline Company & Novartis & Kite/Gilead & Juno/Celgene \\
\hline Source & $\begin{array}{l}\text { Phase } 2 \\
\text { Borchmann et al. [20], } 2018\end{array}$ & $\begin{array}{l}\text { Phase } 2 \\
\text { Neelapu et al. [28], } 2017\end{array}$ & $\begin{array}{l}\text { Phase } 2 \\
\text { Abramson et al. [33], } 2018\end{array}$ \\
\hline CAR & $\begin{array}{l}\text { Second generation, } 41 \mathrm{BB} \\
\text { Lentivirus }\end{array}$ & $\begin{array}{l}\text { Second generation, CD28 } \\
\text { Retrovirus }\end{array}$ & $\begin{array}{l}\text { Second generation, } 41 \mathrm{BB} \\
\text { Retrovirus }\end{array}$ \\
\hline Disease entity & DLBCL, tFL & DLBCL, tFL and PMBCL & $\begin{array}{l}\text { DLBCL, HGBCL, tFL (CORE } \\
\text { cohort) }\end{array}$ \\
\hline Inclusion criteria & $\begin{array}{l}\geq 2 \text { prior lines of therapies for DLB- } \\
\text { CL } \\
\text { PD after or ineligible for auto SCT }\end{array}$ & $\begin{array}{l}\text { No response to last chemotherapy or } \\
\text { relapse }<12 \text { months after ASCT }\end{array}$ & $\geq 2$ prior lines of therapies \\
\hline Enrollment & $\begin{array}{l}165 \text { enrolled } \\
111 \text { dosed } \\
\text { 102/111: bridging chemotherapy } \\
93 \text { evaluable }\end{array}$ & $\begin{array}{l}\text { Phase 1: } \\
7 \text { dosed } \\
\text { Phase } 2 \text { : } \\
111 \text { enrolled } \\
103 \text { conditioned } \\
101 \text { dosed and evaluable } \\
\text { Phases } 1+2: 108 \text { dosed }\end{array}$ & $\begin{array}{l}134 \text { leukapheresis } \\
114 \text { dosed } \\
102 \text { evaluable }\end{array}$ \\
\hline Patient population & $\begin{array}{l}\text { Prior therapies } \geq 3: 52 \% \\
49 \% \text { ASCT } \\
55 \% \text { refractory }\end{array}$ & $\begin{array}{l}\text { Prior therapies } \geq 3: 70 \% \\
23 \% \text { ASCT } \\
74 \% \text { refractory }\end{array}$ & $\begin{array}{l}\text { Median prior therapies } 3(2-8) \\
38 \% \text { ASCT } \\
67 \% \text { refractory }\end{array}$ \\
\hline Dose & $1-5 \times 10^{8}$ CAR T cells & $\begin{array}{l}2 \times 10^{6} \text { CAR T cells } / \mathrm{kg} \\
\text { e.g. } 70 \mathrm{~kg}: 1.4 \times 10^{8}\end{array}$ & $1 \times 10^{8}$ CAR T cells \\
\hline $\begin{array}{l}\text { Lymphodepleting } \\
\text { chemotherapy }\end{array}$ & $\begin{array}{l}\text { Flu } 25 \mathrm{mg} / \mathrm{m}^{2}+\text { Cy } 250 \mathrm{mg} / \mathrm{m}^{2} \times 3 \\
\text { days or bendamustine }\end{array}$ & $\begin{array}{l}\text { Flu } 30 \mathrm{mg} / \mathrm{m}^{2}+\text { Cy } 500 \mathrm{mg} / \mathrm{m}^{2} \times 3 \\
\text { days }\end{array}$ & $\begin{array}{l}\text { Flu } 30 \mathrm{mg} / \mathrm{m}^{2}+\text { Cy } 300 \mathrm{mg} / \mathrm{m}^{2} \times \\
3 \text { days }\end{array}$ \\
\hline Efficacy & $\begin{array}{l}\text { Median FU } 14 \text { months } \\
\text { ORR: } 52 \% \\
\text { CR: } 40 \% \\
\text { 12-month OS: } 49 \% \\
\text { Median OS: CR:NR; all: } 11.7 \\
\text { months }\end{array}$ & $\begin{array}{l}\text { Median FU: } 15.4 \text { months } \\
\text { ORR: } 82 \% \\
\text { CR (I+II): } 58 \% \\
\text { Median OS months: NR (for CR and } \\
\text { PR) }\end{array}$ & $\begin{array}{l}\text { ORR: } 80 \% \\
\text { CR: } 59 \% \\
\text { 12-month OS: } 63 \% \\
\text { Median OS: CR:NR; PR } 10.3 \\
\text { months }\end{array}$ \\
\hline Safety & $\begin{array}{l}\text { Gr } \geq 3 \text { CRS: } 24 \% \text { Penn criteria } \\
\text { Gr } \geq 3 \text { NE: } 12 \% \\
\text { No deaths due to CRS or cerebral } \\
\text { edema }\end{array}$ & $\begin{array}{l}\text { Gr } \geq 3 \text { CRS: } \\
13 \%, \text { Lee criteria } \\
\text { Gr } \geq 3 \text { NE: } 28 \% \\
\text { Gr } 5 \text { AEs Axi-cel related: } 2 \%\end{array}$ & $\begin{array}{l}\text { Gr } \geq 3 \text { CRS: } 1 \% \text { Lee criteria } \\
\text { Gr } \geq 3 \text { NE: } 15 \% \\
\text { No deaths from CRS or NE }\end{array}$ \\
\hline
\end{tabular}

DLBCL, diffuse large B-cell lymphoma; tFL, transformed follicular lymphoma; PMBCL, primary mediastinal large B-cell lymphoma; HGBCL, high-grade B-cell lymphoma; PD, progressive disease; SCT, stem cell transplantation; ASCT, autologous stem cell transplant; Flu, fludarabine; Cy, cyclophosphamide; FU, follow-up; ORR, overall response rate; CR, complete response; OS, overall survival; NR, no response; PR, partial response; Gr, grade; CRS, cytokine release syndrome; NE, no response; AEs, adverse events.

sis of outcomes reported for ZUMA-1 and SCHOLAR-1, the latter being a pooled retrospective analysis of outcomes of refractory DLBCL from 2 large randomized trials and 2 academic databases [32]. To further compare the efficacy of Yescarta ${ }^{\circledR}$ with current treatment standards, a phase III trial was initiated earlier this year. It aims to explore whether CAR T-cell therapy with axicabtagene ciloleucel is more effective than an autologous stem cell transplant in adult r/r DLBCL (ZUMA-7; NCT03391466).
The third CAR T-cell product for the treatment of $r / r$ aggressive NHL is already in the pipeline. Lisocabtagene maraleucel (JCAR017, Celgene) is currently tested in the pivotal phase I TRANSCEND NHL 001 trial (NCT02631044). This CD19-directed 4-1BB CAR T-cell trial showed much lower cytokine release syndrome (CRS) adverse reactions compared to the Novartis and Gilead products. However, efficacy results remain to be published [33]. Trial results are summarized in Table 1. 
Of interest, Kymriah ${ }^{\circledR}$ and Yescarta ${ }^{\circledR}$ are the first therapies supported through the European Medicines Agency's (EMA) Priority Medicines scheme to receive positive opinions from the Committee for Medicinal Products for Human Use. The voluntary Priority Medicines scheme provides scientific and regulatory support to treatments with potential to significantly address patients' unmet medical needs.

\section{Challenges}

Despite the spectacular results achieved with this new development, CAR T-cell therapy has become a topic of discussion because of the severe and common adverse reactions as well as high costs associated with it.

\section{Toxicities and Management}

The range of toxicities associated with CAR T-cell therapy is unique and differs from those seen with traditional chemotherapies and other targeted therapies such as monoclonal antibodies and small-molecule inhibitors. The most common toxicities observed after CAR T-cell therapy are CRS and immune effector cell-associated neurotoxicity syndrome (ICANS). Other adverse reactions include "on-target, off-tumor" recognition and anaphylaxis [34].

\section{Cytokine Release Syndrome}

CRS, also known as "cytokine storm," is a spectrum of inflammatory symptoms due to cytokine elevations as a result of immune activation of large numbers of lymphocytes. IL-6, a pleiotropic cytokine with anti-inflammatory and proinflammatory properties, has been implicated as a central mediator of toxicity in CRS [35]. The incidence and severity of CRS in patients receiving CAR T-cell therapy appears greater in patients with higher disease burden at initiation of treatment [36]. This is probably due to higher levels of T-cell activation [35].

CRS is accompanied by constitutional symptoms such as high fever, malaise, fatigue, myalgia, nausea triggered by an increase in TNF- $\alpha$ at first, followed by IFN- $\gamma$, IL- 1 , IL-2, IL-6, IL-8, and IL-10. In addition, any organ system may be affected, including the cardiovascular, respiratory, renal, hepatic, hematological and nervous system [35, 37-39]. In rare cases, CRS can evolve into fulminant macrophage activation syndrome [39].

Currently, research on identification of predictive biomarkers for severe toxicity is needed, as the correlation between the development of severe CRS and clinical parameters is inconclusive. The predictive values of various biomarkers (e.g., high serum levels of IL-6, soluble gp130, IFN- $\gamma$, IL-15, IL-8, and/or IL-10) seem to vary depending on the type of CAR T-cell product used [40, 41].
CRS toxicity typically develops within the first week after CAR T-cell infusion and peaks within 1-2 weeks, coinciding with maximal in vivo T-cell expansion [35, 39]. CRS should be managed in accordance with the grade of its toxicity. Patient hospitalization with close monitoring is recommended by Neelapu et al. [39] for at least 7-10 days after CAR T-cell infusion. Others have not found this to be necessary in studies using CAR T-cell constructs containing a 4-1BB costimulatory domain, including tisagenlecleucel, in both ALL and NHL populations [42].

Tocilizumab, a therapeutic antibody blocking IL-6 receptors, or the chimeric anti-IL-6 monoclonal antibody siltuximab binding to soluble IL- 6 have become the drugs of choice for the management of moderate to severe CRS. In Europe, both drugs are currently used off-label for the management of CRS and induce near-immediate reversal of CRS symptoms in most patients. In August 2017, tocilizumab has been approved by the FDA for the treatment of CRS occurring after CAR T-cell therapy $[38,43]$. The EMA's Committee for Medicinal Products for $\mathrm{Hu}-$ man Use has also recommended adding the treatment of CAR T-cell-induced CRS as an indication for tocilizumab [44]. Approval has not been granted at the time of writing but is expected any time soon. Tocilizumab does not seem to affect the efficacy of CAR T-cell therapy in terms of overall response rates, CR rates, or the durability of responses $[39,45,46]$. Siltuximab on the other hand has not been studied as first-line therapy for CRS and is not currently FDA-approved for this indication [42]. Comparative studies are needed to directly compare the effectiveness of tocilizumab and siltuximab in the treatment of CRS. The use of corticosteroids is generally considered only when the toxicities of CAR T-cell therapy are refractory to anti-IL-6 therapy due to concerns regarding their suppressive action on T-cell function [39].

\section{Immune Effector Cell-Associated Neurotoxicity}

Syndrome

Neurotoxicity is the second most common serious adverse reaction after administration of CAR T-cell therapy and was therefore initially termed "CAR T-cell-related encephalopathy syndrome" and has currently been updated by Lee et al. [47] to "immune effector cell-associated neurotoxicity syndrome (ICANS)". Affected patients develop toxic encephalopathy with confusion, aphasia, ataxia, delirium, seizures, and cerebral edema. The causative pathophysiology of these neurological side effects is still not fully understood. It can occur concurrently with CRS, although the neurotoxicity does not seem to be directly related [35]. It has been completely reversible in most cases and it is unclear whether this toxicity is restricted to CD19-specific CAR T cells or will be exhibited by the targeting of other tumor-associated antigens $[38,46,48]$. 
According to Neelapu et al. [39], the manifestation of ICANS can be biphasic; the first phase occurs concurrently with high fever and other CRS symptoms, typically within the first 5 days after cellular immunotherapy, and the second phase occurs after the fever and other CRS symptoms have subsided, often beyond 5 days after cell infusion. Anti-IL-6 therapy can reverse ICANS during the first phase but is generally not effective in the second phase, when corticosteroids are the preferred treatment [39]. The severity of ICANS can fluctuate rapidly, thus, necessitating close patient monitoring $[40,41]$. This is especially important for the very rare, but life-threatening cerebral edema, for which anti-IL-6 therapy is not effective [39]. Similar to CRS, management of ICANS is based on the severity of the adverse reactions.

In the future, targeted intervention against IL-1 may successfully overcome both toxicities, as shown in the mouse model [49]. Meanwhile, the acute toxicities of CAR T-cell therapy require intensive monitoring. Prompt management of CRS and ICANS can be lifesaving. The EMA has elaborated monitoring and mitigation strategies involving educational programs for patients and health care providers as an integral part of the authorization.

\section{CAR Costs}

With the clinical application of approved CAR T-cell therapy still being in its earliest stages, the cost of treatment is enormous. In the USA, treatment with Yescarta ${ }^{\circledR}$ costs USD 373,000 (EUR 316,000), whereas $\mathrm{Kymriah}^{\circledR}$ therapy comes up to USD 475,000 per patient (EUR 400,000). Manufacturers justify the extreme price tag with the complexity of CAR T-cell therapy, which requires individual manufacturing for each patient and sample transportation between specialized centers. These costs do not include hospital stay, supportive care and medication, or physician visits, which - in the USA could amount to total treatment costs of more than USD $1,000,000$. European countries often negotiate prices that are significantly lower than in the USA [50, 51]. Following the approval of Yescarta ${ }^{\circledR}$ and $\mathrm{Kymriah}^{\circledR}$ in the EU, pricing and reimbursement is up to each individual country member.

The UK's National Institute for Health and Care Excellence (NICE) - the body that assesses new medications and treatments for use on the National Health Service does not recommend use of Yescarta ${ }^{\circledR}$, due to a lack of cost-effectiveness and comparative data with salvage chemotherapy. The appraisal committee, however, made it clear that this decision was not final and will be discussed again with experts [52].

Only 1 week after the announcement, Novartis struck a deal with the NICE to provide Kymriah ${ }^{\circledR}$ for relapsed childhood leukemia in the UK at a discount, so it can be offered through the UK's social health care system. Such an agreement is the first of its kind in Europe and one of the fastest in European history [53, 54].

\section{A CAR for Every Purpose?}

Following the great success of CAR T-cell therapy in ALL and B-cell lymphoma, more research is being done to extend this treatment to other malignancies, and first attempts to target solid tumors were performed. So far, treatment of solid tumors with CAR T-cells has yielded mixed results.

A main obstacle is finding a potent target antigen expressed in the tumor but not in healthy tissue, to avoid severe toxicities, as seen in several clinical trials [55-58]. In this regard, one noteworthy approach with promising efficacy in patients with $\mathrm{r} / \mathrm{r}$ multiple myeloma is the B-cell maturation antigen-targeting CAR T-cell therapybb2121, a second-generation CAR. Updated results from the ongoing 2-part, phase I study CRB-401 showed that bb2121 induced deep and durable response in heavily pretreated multiple myeloma patients. CRS and neurotoxicity were manageable, thus bb2121 anti-B-cell maturation antigen CAR T-cell therapy has the potential to become a new treatment paradigm for $\mathrm{r} / \mathrm{r}$ multiple myeloma [59]. Future CAR T cells are expected to target multiple antigens, so the loss of one specific molecule will no longer be of therapeutic importance.

To limit systemic exposure, the next developmental step was to administer the CAR T cells directly into the tumor. To give one example of this approach, CAR T cells against IL-13 were injected into glioblastoma multiforme, inducing regression without adverse reactions [60]. Another potential target antigen is the HER2 protein, as it is widely expressed not only in breast cancer, but also by many common pediatric brain tumors. The phase I trial BrainChild-01 (NCT03500991) started investigating the potential of third-generation CAR T cells targeting HER2expressing tumor cells, administered directly via an indwelling CNS catheter.

The immunosuppressive microenvironment of solid tumors also plays an important role in therapeutic resistance. Penetration of CAR T cells into solid tissue is obviously more difficult, and it is unclear to which degree Tcell expansion and persistence within the tumor are required to ensure clinical efficacy [15]. Another evasive pathway of solid tumors is upregulation of inhibitory receptors, such as PD1/PD-L1 and CTL4. As a countermeasure, joint action of so-called checkpoint inhibitors and CAR T cells was tested in mice and showed promising results [61]. Similarly, the combination of CAR T cells with BiTE-expressing oncolytic adenovirus might overcome the limitations of monotherapies in solid tumors 
[62]. Obtaining such positive results in solid cancer treatment emphasizes the vast potential for CAR T-cell therapies and the importance of their future development.

\section{Conclusion}

Until recently, CAR T-cell therapy has only been available to a very small group of patients with advanced hematological malignancies. Although the use of this emerging treatment has so far been largely restricted to small clinical trials, its advance has been followed with great interest by researchers and clinicians alike. The remarkable responses seen in children and adults with certain leukemias and B-cell lymphomas from whom no other therapy was effective bring new hope to affected patients. The first two CAR T-cell medicines have been reviewed in Europe under an accelerated assessment program, giving credit to the benefits seen with this breakthrough treatment option.

However, there are still a lot of questions which need to be answered by generating more data through randomized trials. What is the optimal timing for the use of CAR T cells? Can this therapy be administered even more safely earlier in the disease course? Which patients benefit the most from these therapies? To answer this, further biomarkers need to be identified to target the treatments more specifically and effectively to the patient. Can CAR T-cell therapy replace an alloSCT? We await with interest results from currently ongoing trials investigating the use of autologous SCT versus CAR T-cell therapy in relapse B-cell lymphoma patients. CAR T cells may one day be used as a method to eradicate minimal residual disease in ALL patients.

While all of this is currently still up in the air, we have important issues to face in the here and now. The intense immune activation result in severe adverse reactions, which need to be managed appropriately to allow successful clinical use of CAR T cells. An example for this integral step is the service provided by the ImmunoTaskForce $\mathrm{e}^{\mathrm{LMU}}$ at the Ludwig-Maximilian University Munich (LMU). We have established an interdisciplinary ImmunoTaskForce $^{\mathrm{LMU}}$ with broad experience in T-cell-based treatments. A $24 / 7$ on-call service is offered by a highly specialized team consisting of experienced hematologists with training in allogeneic stem cell transplantation, Tcell-based immunotherapy and intermediate/intensive care. The Task Force also includes members of the transfusion medicine department and is complemented by a team of neurologists and neuroradiologists specifically trained for BiTE and CAR T-cell patient care. This aims to ensure patient safety as we have to be aware that suboptimal patient management can endanger CAR T-cell development. Other critical factors for success are economizing the complex manufacturing process and developing more cost-effective solutions - only then will the new technology be pushed forward in broad terms and for other cancer entities as well.

Following the recent approval of the first marketing authorizations for CD19-specific CAR T cells in the USA and Europe, CAR T cells are developed for the treatment of other cancers, including multiple myeloma, mammary carcinoma and CNS tumors. It is hoped that CAR T-cell therapy could eventually replace chemotherapy and stem cell transplants altogether.

Results in solid cancers have been mixed so far, since therapy is more complicated than in hematological malignancies. Clearly, CAR T cells for entities other than lymphoid malignancies face the challenge of identifying suitable target antigens. In solid tumors, the clinical translation is facing the difficulties of getting $T$ cells to infiltrate and persist in the tissue long enough to effect an antitumor response.

Definitely, these are still early days for CAR T cells, but if positive results are obtained in future clinical trials, this would allow the use of this revolutionary immunotherapy for a wide variety of tumors. Investigations on the occurrence and management of adverse reactions and the implementation of risk minimization measures will then receive an even higher priority. These include the use of the products in highly specialized centers, the training of medical staff, and the provision of medicinal products for the treatment of CRS.

One thing is already clear today: the CAR T-cell technology of cancer medicine opens a new door. What opportunities and challenges lie behind it remains to be discovered.

\section{Statement of Ethics}

The authors have no ethical conflicts to disclose.

\section{Disclosure Statement}

M.S. has in the past received honoraria from Amgen, Roche, Gilead, Novartis, Celgene, and Seattle Genetics. M.S. has received research funding from Amgen, Roche, Gilead, and Morphosys.

\footnotetext{
References $\quad 1$ Kolb HJ. Donor leukocyte transfusions for treatment of leukemic relapse after bone marrow transplantation. EBMT Immunology and Chronic Leukemia Working Parties. Vox Sang. 1998;74(2 Suppl 2):321-9.

2 Riethmüller G. Symmetry breaking: bispecific antibodies, the beginnings, and 50 years on. Cancer Immun. 2012;12:12.

3 Velasquez MP, Bonifant CL, Gottschalk S. Redirecting $\mathrm{T}$ cells to hematological malignancies with bispecific antibodies. Blood. 2018 Jan;131(1):30-8.
} 
4 Zugmaier G, Gökbuget N, Klinger M, Viardot A, Stelljes M, Neumann S, et al. Long-term survival and $\mathrm{T}$-cell kinetics in relapsed/refractory ALL patients who achieved MRD response after blinatumomab treatment. Blood. 2015 Dec;126(24):2578-84

5 European Medicines Agency [Internet]. Blincyto (blinatumomab). Assessment history [cited 2018 Sep 05]. Available from: http:// www.ema.europa.eu/e ma / index. jsp?curl=pages/medicines $/$ human $/$ medicines/003731/human_med_001921. jsp\&mid=WC0b01ac058001d124.

6 Topp MS, Gökbuget N, Stein AS, Zugmaier G, O'Brien S, Bargou RC, et al. Safety and activity of blinatumomab for adult patients with relapsed or refractory B-precursor acute lymphoblastic leukaemia: a multicentre, singlearm, phase 2 study. Lancet Oncol. 2015 Jan; 16(1):57-66.

7 Kantarjian H, Stein A, Gökbuget N, Fielding AK, Schuh AC, Ribera JM, et al. Blinatumomab versus Chemotherapy for Advanced Acute Lymphoblastic Leukemia. N Engl J Med. 2017 Mar;376(9):836-47.

8 Duell J, Dittrich M, Bedke T, Mueller T, Eisele $\mathrm{F}$, Rosenwald A, et al. Frequency of regulatory $\mathrm{T}$ cells determines the outcome of the T-cellengaging antibody blinatumomab in patients with B-precursor ALL. Leukemia. 2017 Oct 31(10):2181-90.

9 Brocker T, Karjalainen K. Signals through T cell receptor-zeta chain alone are insufficient to prime resting T lymphocytes. J Exp Med. 1995 May;181(5):1653-9.

10 Gong MC, Latouche JB, Krause A, Heston WD, Bander NH, Sadelain M. Cancer patient T cells genetically targeted to prostate-specific membrane antigen specifically lyse prostate cancer cells and release cytokines in response to prostate-specific membrane antigen. Neoplasia. 1999 Jun;1(2):123-7.

11 Krause A, Guo HF, Latouche JB, Tan C, Cheung NK, Sadelain M. Antigen-dependent CD28 signaling selectively enhances survival and proliferation in genetically modified activated human primary T lymphocytes. J Exp Med. 1998 Aug;188(4):619-26.

12 Porter DL, Levine BL, Kalos M, Bagg A, June $\mathrm{CH}$. Chimeric antigen receptor-modified $\mathrm{T}$ cells in chronic lymphoid leukemia. $\mathrm{N}$ Engl Med. 2011 Aug;365(8):725-33.

13 Brentjens RJ, Curran KJ. Novel cellular therapies for leukemia: CAR-modified T cells targeted to the CD19 antigen. Hematology Am Soc Hematol Educ Program. 2012;2012:14351.

14 Wang LC, Lo A, Scholler J, Sun J, Majumdar RS, Kapoor V, et al. Targeting fibroblast activation protein in tumor stroma with chimeric antigen receptor $\mathrm{T}$ cells can inhibit tumor growth and augment host immunity without severe toxicity. Cancer Immunol Res. 2014 Feb;2(2):154-66.

15 Scarfò I, Maus MV. Current approaches to increase CAR $\mathrm{T}$ cell potency in solid tumors: targeting the tumor microenvironment. J Immunother Cancer. 2017 Mar;5(1):28.

16 Wang X, Rivière I. Clinical manufacturing of CAR T cells: foundation of a promising therapy. Mol Ther Oncolytics. 2016 Jun;3:16015.
17 Levine BL, Miskin J, Wonnacott K, Keir C. Global manufacturing of CAR T cell therapy. Mol Ther Methods Clin Dev. 2016 Dec;4:92101

18 Fesnak AD, Suhoski Davis MM, Levine BL. Production of chimeric antigen receptor $\mathrm{T}$ cells. Stemcell Technologies. Poster. Nature Protocols. 2017;12(4). www.stemcell.com/ media/files/wallchart/WA27041-Production_of_Chimeric_Antigen_Receptor_T_ cells.pdf.

19 Vannucci L, Lai M, Chiuppesi F, CeccheriniNelli L, Pistello M. Viral vectors: a look back and ahead on gene transfer technology. New Microbiol. 2013 Jan;36(1):1-22.

20 Borchmann P, Tam CS, Jager U, et al. An updated analysis of JULIET, a global pivotal phase 2 trial of tisagenlecleucel in adult patients with relapsed or refractory $(\mathrm{r} / \mathrm{r})$ diffuse large B-cell lymphoma (DLBCL) [abstract]. The 23rd Congress of EHA; June 14-17; Stockholm.

21 Singh H, Huls H, Kebriaei P, Cooper LJ. A new approach to gene therapy using Sleeping Beauty to genetically modify clinical-grade $\mathrm{T}$ cells to target CD19. Immunol Rev. 2014 Jan; 257(1):181-90.

22 Levine BL, Bernstein WB, Connors M, Craighead N, Lindsten T, Thompson CB, et al. Effects of CD28 costimulation on long-term proliferation of CD4+ T cells in the absence of exogenous feeder cells [Abstract]. J Immunol. 1997 Dec;159(12):5921-30.

23 Suhoski MM, Golovina TN, Aqui NA, Tai VC, Varela-Rohena A, Milone MC, et al. Engineering artificial antigen-presenting cells to express a diverse array of co-stimulatory molecules. Mol Ther. 2007 May;15(5):981-8.

24 Maude SL, Laetsch TW, Buechner J, Rives S, Boyer M, Bittencourt $\mathrm{H}$, et al. Tisagenlecleucel in Children and Young Adults with B-Cell Lymphoblastic Leukemia. N Engl J Med. 2018 Feb;378(5):439-48.

25 Long AH, Haso WM, Shern JF, Wanhainen KM, Murgai M, Ingaramo M, et al. 4-1BB costimulation ameliorates $\mathrm{T}$ cell exhaustion induced by tonic signaling of chimeric antigen receptors. Nat Med. 2015 Jun;21(6):581-90.

26 Zhang LN, Song Y, Liu D. CD19 CAR-T cell therapy for relapsed/refractory acute lymphoblastic leukemia: factors affecting toxicities and long-term efficacies. J Hematol Oncol. 2018 Mar;11(1):41.

27 Rose S. First-Ever CAR T-cell Therapy Approved in U.S. Cancer Discov. 2017 Oct; 7(10):OF1.

28 Neelapu SS, Locke FL, Bartlett NL, Lekakis LJ, Miklos DB, Jacobson CA, et al. Axicabtagene Ciloleucel CAR T-Cell Therapy in Refractory Large B-Cell Lymphoma. N Engl J Med. 2017 Dec;377(26):2531-44.

29 Mulcahy N [Internet]. First CAR T cells approved in Europe - Medscape - Aug 27, 2018 [cited 2018 Sep 06]. Available from: https:// www.medscape.com/viewarticle/901231_print.

30 Roberts ZJ, Better M, Bot A, Roberts MR, Ribas A. Axicabtagene ciloleucel, a first-in-class CAR T cell therapy for aggressive NHL. Leuk Lymphoma. 2018 Aug;59(8):1785-96.
31 Neelapu S, Locke F, Bartlett N, Lekakis L, Reagan $\mathrm{P}$, Miklos $\mathrm{D}$, et al. SCHOLAR-1 versus ZUMA-1: a standardized comparison of outcomes in patients (Pts) with refractory, aggressive non-Hodgkin lymphoma (rNHL) [Abstract]. Clin Lymphoma Myeloma Leuk. 2017 Sep;17:S362-3.

32 Crump M, Neelapu SS, Farooq U, Van Den Neste E, Kuruvilla J, Westin J, et al. Outcomes in refractory diffuse large B-cell lymphoma: results from the international SCHOLAR-1 study. Blood. 2017 Oct; 130(16):1800-8.

33 Abramson JS, Gordon LI, Palomba ML, Lunning MA, Arnason JE, Forero-Torres A, et al. Updated safety and long term clinical outcomes in TRANSCEND NHL 001, pivotal trial of lisocabtagene maraleucel (JCAR017) in r/r aggressive NHL. J Clin Oncol. 2018; 36(suppl): abstr 7505 .

34 Bonifant CL, Jackson HJ, Brentjens RJ, Curran KJ. Toxicity and management in CAR Tcell therapy. Mol Ther Oncolytics. 2016 Apr; 3:16011.

35 Lee DW, Gardner R, Porter DL, Louis CU, Ahmed N, Jensen M, et al. Current concepts in the diagnosis and management of cytokine release syndrome. Blood. 2014 Jul;124(2): 188-95.

36 Shimabukuro-Vornhagen A, Gödel P, Subklewe M, Stemmler HJ, Schlößer HA, Schlaak $\mathrm{M}$, et al. Cytokine release syndrome. J Immunother Cancer. 2018 Jun;6(1):56.

37 Brudno JN, Kochenderfer JN. Toxicities of chimeric antigen receptor $\mathrm{T}$ cells: recognition and management. Blood. 2016 Jun;127(26) 3321-30.

38 Maude SL, Barrett D, Teachey DT, Grupp SA Managing cytokine release syndrome associated with novel $\mathrm{T}$ cell-engaging therapies. Cancer J. 2014 Mar-Apr;20(2):119-22.

39 Neelapu SS, Tummala S, Kebriaei P, Wierda W, Gutierrez C, Locke FL, et al. Chimeric antigen receptor T-cell therapy - assessment and management of toxicities. Nat Rev Clin Oncol. 2018 Jan;15(1):47-62.

40 Turtle CJ, Hanafi LA, Berger C, Hudecek M, Pender B, Robinson E, et al. Immunotherapy of non-Hodgkin's lymphoma with a defined ratio of CD8+ and CD4+ CD19-specific chimeric antigen receptor-modified T cells. Sci Transl Med. 2016 Sep;8(355):355ra116.

41 Teachey DT, Lacey SF, Shaw PA, Melenhorst JJ, Maude SL, Frey N, et al. Identification of Predictive Biomarkers for Cytokine Release Syndrome after Chimeric Antigen Receptor T-cell Therapy for Acute Lymphoblastic Leukemia. Cancer Discov. 2016 Jun; 6(6):664-79.

42 Teachey DT, Bishop MR, Maloney DG Grupp SA. Toxicity management after chimeric antigen receptor $\mathrm{T}$ cell therapy: one size does not fit 'ALL'. Nat Rev Clin Oncol. 2018 Apr;15(4):218.

43 Grupp SA, Kalos M, Barrett D, Aplenc R, Porter DL, Rheingold SR, et al. Chimeric antigen receptor-modified $\mathrm{T}$ cells for acute lymphoid leukemia. N Engl J Med. 2013 Apr;368(16): 1509-18. 
44 European Medicines Agency [Internet]. First two CAR-T cell medicines recommended for approval in the European Union. Development of Kymriah and Yescarta supported through PRIME [cited 2018 Sep 02]. Available from: http://www.ema.europa.eu/ema/index. jsp? curl=pages/news_and_events/ news/2018/06/news_detail_002983. jsp\&mid=WC0b01ac058004d5c1.

45 Maude SL, Frey N, Shaw PA, Aplenc R, Barrett DM, Bunin NJ, et al. Chimeric antigen receptor T cells for sustained remissions in leukemia. N Engl J Med. 2014 Oct;371(16):150717.

46 Davila ML, Riviere I, Wang X, Bartido S, Park J, Curran K, et al. Efficacy and toxicity management of 19-28z CAR T cell therapy in B cell acute lymphoblastic leukemia. Sci Trans Med. 2014 Feb;6(224):224ra25.

47 Lee DW, Santomasso BD, Locke FL, Ghobadi A, Turtle CJ, Brudno JN, et al. ASBMT Consensus Grading for Cytokine Release Syndrome and Neurological Toxicity Associated with Immune Effector Cells. Biol Blood Marrow Transplant. 2018 Dec 25; pii: S10838791(18)31691-4 [Epub ahead of print].

48 Lee DW, Kochenderfer JN, Stetler-Stevenson M, Cui YK, Delbrook C, Feldman SA, et al. T cells expressing CD19 chimeric antigen receptors for acute lymphoblastic leukaemia in children and young adults: a phase 1 dose-escalation trial. Lancet. 2015 Feb;385(9967): 517-28.

49 Norelli M, Camisa B, Barbiera G, Falcone L, Purevdorj A, Genua M, et al. Monocyte-derived IL- 1 and IL- 6 are differentially required for cytokine-release syndrome and neurotoxicity due to CAR T cells. Nat Med. 2018 Jun; 24(6):739-48
50 Szabo L [Internet]. Cascade of costs could push new gene therapy above \$1 million per patient. Kaiser Health News [cited 2018 Sep 05]. Available from: https://khn.org/news/cascade-of-costs-could-push-new-gene-therapy-above-1-million-per-patient.

51 Cavallo J [Internet]. Weighing the cost and value of CAR T-cell therapy. A roundtable discussion with Carl H. June, MD; Sagar Lonial, MD; David G. Maloney, MD, PhD; and Pascal Touchon [cited 2018 Sep 08]. Available from: http://www.ascopost.com/issues/may25-2018/weighing-the-cost-and-value-ofcar-t-cell-therapy/.

52 National Institute for Health and Care Excellence (NICE) [Internet]. Axicabtagene ciloleucel for treating diffuse large B-cell lymphoma and primary mediastinal B-cell lymphoma after 2 or more systemic therapies [ID1115] [cited 2018 Sep 08]. Available from: https://www.nice.org.uk/guidance/indevelopment/gid-ta10214.

53 Hawkes N [Internet]. Childhood leukaemia: Novartis immunotherapy drug approved after deal with NHS. BMJ 2018;362:k3799 [cited 2018 Sep 08]. Available from: https://www. bmj.com/content/362/bmj.k3799.

54 Forster V [Internet]. England's Health Service does deal with Novartis to provide Kymriah for relapsed childhood leukemia. Published online on 05 Sep 2018 [cited 2018 Sep 08]. Available from: https://www.forbes.com/sites/ victoriaforster/2018/09/05/u-k-s-health-service-reaches-deal-with-novartis-to-providekym riah-for - relapsed - childhood leukemia/\#111192517db0.

55 Lamers CH, Sleijfer S, Vulto AG, Kruit WH, Kliffen M, Debets R, et al. Treatment of metastatic renal cell carcinoma with autologous Tlymphocytes genetically retargeted against carbonic anhydrase IX: first clinical experience. J Clin Oncol. 2006 May;24(13):e20-2.
56 Morgan RA, Yang JC, Kitano M, Dudley ME, Laurencot CM, Rosenberg SA. Case report of a serious adverse event following the administration of $\mathrm{T}$ cells transduced with a chimeric antigen receptor recognizing ERBB2. Mol Ther. 2010 Apr;18(4):843-51.

57 Ahmed N, Brawley VS, Hegde M, Robertson C, Ghazi A, Gerken C, et al. Human Epidermal Growth Factor Receptor 2 (HER2) -Specific Chimeric Antigen Receptor-Modified T Cells for the Immunotherapy of HER2-Positive Sarcoma. J Clin Oncol. 2015 May;33(15): 1688-96.

58 Schmidt C. The struggle to do no harm in clinical trials. Nature. 2017 Dec;552(7685): S74-5.

59 Raje NS, Berdeja JG, Lin Y, Munshi NC, DiCapua Siegel DS, Liedtke M, et al. bb2121 anti-BCMA CAR T-cell therapy in patients with relapsed/refractory multiple myeloma: updated results from a multicenter phase I study. J Clin Oncol. 2018;36(suppl): abstr 8007.

60 Brown CE, Alizadeh D, Starr R, Weng L, Wagner JR, Naranjo A, et al. Regression of Glioblastoma after Chimeric Antigen Receptor T-Cell Therapy. N Engl J Med. 2016 Dec; 375(26):2561-9.

61 John LB, Devaud C, Duong CP, Yong CS, Beavis PA, Haynes NM, et al. Anti-PD-1 antibody therapy potently enhances the eradication of established tumors by gene-modified T cells. Clin Cancer Res. 2013 Oct;19(20): 5636-46.

62 Wing A, Fajardo CA, Posey AD Jr, Shaw C, Da T, Young RM, et al. Improving CART-Cell Therapy of Solid Tumors with Oncolytic Virus-Driven Production of a Bispecific T-cell Engager. Cancer Immunol Res. 2018 May; 6(5):605-16. 